\title{
Aktivitas Dakwah di Masa New Normal
}

\author{
Ibnu Hajar Sainuddin \\ STAI DDI Kota Makassar \\ Email: dewaibnuhajar@gmail.com
}

\begin{abstract}
ABSTRAK
Pandemi covid-19 banyak terjadi perubahan dalam kehidupan manusia. Perubahan yang terjadi diakibatkan oleh pandemi ini yaitu dari segi kehidupan sehari-hari, aktivitas ekonomi, sosial, budaya dan keagamaan. Dari segi keagamaan terjadi perubahan seperti dakwah yang terbatas baik segi waktu maupun dari segi kuantitas seperti pembatasan jamaah dan tempat keagamaan yang dapat mengakibatkan terjadinya penularan covid-19.
\end{abstract}

Kata Kunci: Aktivitas, Dakwah, New Normal

\section{Pendahuluan}

Islam adalah agama dakwah yang disebarluaskan dan diperkenalkan kepada umat manusia melalui aktivitas dakwah yang dilakukan tanpa pemaksaan, kekerasan bahkan sampai dengan kekuatan senjata (Kurniawan, 2018). Dakwah pada hakikatnya mengajak manusia kepada jalan kebaikan, baik secara individu maupun secara berkolompok (Sumadi, 2016). Salah satu cara untuk mencapai nilai dalam kehidupan adalah dengan melalui aktivitas dakwah.

Setelah beberapa bulan dunia mengalami musibah wabah pandemi covid-19 yang cukup berbahaya bahkan sampai merenggut banyak nyawa. Banyak kegiatan keagamaan dilakukan secara terbatas bahkan ditiadakan, baik secara kuantitas atau jumlah peserta atau melalui media komunkasi virtual lainnya (Budiman, 2017). Dengan transformasi dakwah dapat memudahkan kegiatan aktivitas dakwah (Sainuddin, 2020). Dengan diumumkannya pemerintah melalui media bahwa Indonesia sudah memasuki tahap new normal atau adaptasi kebiasan baru, kegiatankegiatan yang bersifat keagamaan mulai dibuka akan tetapi masih masih terbatas jumlahnya dengan menerapkan protokol kesehatan.

\section{Pembahasan}

Sejak pertama kali kasus covid-19 terjadi di Wuhan China, dunia sudah mengambil Langkah preventif dengan melakukan pembatasan kegiatan di berbagai sektor seperti ekonomi, pemerintahan dan tidak terkecuali pada kegiatan keagamaan (Kriswibowo, 2020). Di Indonesia dengan pemeluk agama Islam terbesar di dunia, 
maka juga terjadi pembatasan seperti beribadah di rumah bahkan kegiatan Ramadhan sampai hari raya idul fitri hampir semua dilaksanakan di rumah.

Seperti ibadah haji dan umrah yang dibatasi, (Hajar, 2014) Pembatasan kegiatan dengan berkativitas di rumah membuat banyak orang memanfaatkan untuk lebih dekat dengan keluarga yang sebelumnya sibuk dengan rutinitas pekerjaan di kantor atau di perusahaan. Dengan pembatasan tersebut, maka masyarakat banyak memanfaatkan media sosial untuk menimba ilmu agama seperti melalui instagram, facebook atau sosial media lainnya (Sainuddin, 2020).

Kegiatan dakwah juga mulai bertransformasi dengan sangat cepat khususnya melalau virtual (Anwar, 2019). Dengan melalui virtual seperti aplikasi zoom dan media virtual lainnya, maka masyarakat banyak menggunakan untuk mengikuti kajian-kajian keagamaan langsung. Ini menandakan bahwa masyarakat membutuhkan asupan spiritual yang berbasis keagamaan.

Namun, setelah melalui beberapa bulan pandemi global berlangsung, beberapa negara sudah mulai melakukan pelonggaran aktivitas bahkan negara Indonesia (Agnia, 2020). Dengan pelonggaran tersebut, maka diistilahkan new normal atau adaptasi kebiasaan baru yaitu beraktivitas seperti biasa dengan menerapkan protokol kesehatan seperti memakai masker, rajin mencuci tangan, dan menjaga jarak. Begitupun kegiatan keagamaan sudah dibuka seperti kegiatan ceramah bertatap muka langsung dengan jamaah tetapi dengan protokol kesehatan.

Dengan demikian, artikel ini menunjukkan bahwa aktivitas dakwah di masa new normal merupakan kembalinya kegiatan dakwah dengan menerapkan protokol Kesehatan dengan perbandingan (Farihah, 2018) yang membahas tentang aktivitas dakwah Kiai Pesisiran, (Zaenuri, 2020) yang membahas tentang konsepsi fikih jamaah tablig di masa pandemi. Oleh karena itu, aktivitas dakwah di masa new normal berjalan seperti biasa akan tetapi dengan menerapkan protokol kesehatan berdasarkan himbauan dari pemerintah agar tidak terjadi penularan covid-19.

\section{Penutup}

Aktivitas dakwah di masa new normal telah berjalan seperti biasa akan tetapi dengan menerapkan protokol kesehatan yang diimbau oleh pemerintah dalam rangka mencegah dan memutus rantai penularan agar tidak terjadi penularan covid-19 yang dapat menambah jumlah penularan covid-19.

\section{Daftar Pustaka}

Aghnia Maulida, N. (2020). Pengembangan Diri di Tengah Pandemi Covid-19 sebagai Bagian Aktualisasi Nilai Bela Negara (Self Development in the Middle of 
Covid-19 Pandemic as a Part of Actualization of State Defending Value). Pengembangan Diri di Tengah Pandemi Covid-19 sebagai Bagian Aktualisasi Nilai Bela Negara (Self Development in the Middle of Covid-19 Pandemic as a Part of Actualization of State Defending Value)(June 6, 2020).

Anwar, S. (2019). Revolusi Industri 4.0 Islam Dalam Merespon Tantangan Teknologi Digitalisasi. Jurnal Studi Keislaman, 8(2).

Budiman, H. (2017). Peran teknologi informasi dan komunikasi dalam pendidikan. AlTadzkiyyah: Jurnal Pendidikan Islam, 8(1), 31-43.

Farihah, I., \& Ismanto, I. (2018). Dakwah Kiai Pesisiran: Aktivitas Dakwah Para Kiai di Kabupaten Lamongan. Ilmu Dakwah: Academic Journal for Homiletic Studies, 12(1), 46-60.

Hajar S, I. (2014). Sistem Pengelolaan Bimbingan Manasik Haji-Umrah pada PT. AlBayan Permata Ujas (Doctoral dissertation, Universitas Islam Negeri Alauddin Makassar).

Kriswibowo, A., \& Utomo, S. A. P. (2020). Ekonomi Politik Indonesia di Tengah Pandemi Covid-19. Penerbit Cakradewa Ilmu.

Kurniawan, A. (2018). DAKWAH QASIDAH MODEREN AL-FALAH MELALUI MUSIK. ORASI: Jurnal Dakwah dan Komunikasi, 9(2), 43-58.

Sainuddin, I. H. (2020). Dakwah di Era Sosial Media. 10.31219/osf.io/2jxny

Sainuddin, I. H. (2020). Transformasi Dakwah di Masa Pandemi Covid-19. 10.31219/osf.io/nakhy

Sumadi, E. (2016). Dakwah dan Media Sosial: Menebar Kebaikan Tanpa Diskrimasi. Komunikasi Penyiaran Islam, 1(1), 173-190.

Zaenuri, A. (2020). KONSEPSI FIKIH DAKWAH JAMĀ'AH TABLĪGH PADA MASA PANDEMI COVID-19: Telaah Gerakan Dakwah Jamā'ah Tablīgh Gorontalo. JIL: Journal of Islamic Law, 1(2), 1-23. 